\title{
THE RELATIONSHIP BETWEEN ISLAMIC INDICES AND COMMODITY MARKETS IN TURKEY: EVIDENCE FOURIER- BASED APPROACHES
}

\author{
Şakir Sakarya', Feyyaz Zeren² and Hilmi Tunahan Akkuş ${ }^{1}$ \\ 'Department of Business Administration, Balıkesir University, Balıkesir, Turkey \\ 2Department of International Trade and Finance, Yalova University, Yalova, Turkey
}

\begin{abstract}
Affecting a significant portion of the world economy, the commodity market is the world's largest "nonfinancial" market. In addition to the other macroeconomic variables, commodity prices have a special importance for Islamic stock indices, which have improved in recent years because Islamic finance is a financial system based on the profit/loss sharing principle and supports the real sector's activities. In this study, cointegration and the causality relationship between commodity markets (the Gold ounce and Brent oil) and the Participation-30 Index established by taking Islamic criteria into account were investigated in Turkey. As a result of the analysis, no cointegration relation was found between the Participation-30 Index and the commodity markets. According to these results, an investor investing in gold or oil will, in addition to the Participation-30 Index, diversify its portfolio with this commodity investment and minimize its risk. The fact that there is no relation between the variables according to the causality results indicates that the Participation-30 Islamic Indices' structure is independent of commodity markets and conventional stock markets.
\end{abstract}

Keywords: Participation-30 Islamic Indices, commodity markets, Fourier-based approaches, portfolio diversification

\section{INTRODUCTION}

The fact that the stock market performance can be affected by commodity markets makes the relationship between commodity markets and

* Correspondence to: F. Zeren, Department of International Trade and Finance, Yalova University, Yalova, Turkey;

e-mail: feyyaz.zeren@yalova.edu.tr stock markets significant. In addition to the other macroeconomic variables, commodity prices have a special importance for Islamic stock indices, which have improved in recent years because Islamic finance is a financial system based on the profit/loss sharing principle and is especially supportive of the real sector's activities. In addition, the quantitative criteria needed in the formation of Islamic stock indices 
require that some ratios related to liquidity, interest rates, indebtedness and undesirable gains should be provided. This situation may force the enterprises included in the index to turn to real markets. Therefore, the relationship between Islamic indices and commodity markets is expected and considered to be important.

After the dot.com bubble burst in 2000, i.e. the collapse of high-tech companies' (mainly Internet companies') shares, commodity prices and commodity investment levels increased significantly. Commodity markets enable investors to benefit more from the commodity markets that have a negative price relationship with bonds and stocks in order to diversify their portfolios and also provide investors with the return they seek (Doyle, Hill \& Jack, 2007, 5).

Apart from the low returns obtained from bonds and volatile stock markets, what can make commodity markets advantageous in terms of their attracting investors and preserving the existing investment is a negative correlation between commodities and bonds and stocks, on the one hand, and a positive correlation between commodities and inflation (Doyle et al, 2007, 45). Commodity markets affect an important part of the world economy and are considered to be the world's largest "nonfinancial" market (Doyle et al, 2007, 15; Junkus, 2010, 89). Each one of the commodities in these markets includes a wide range of products with specific demand and supply fundamentals (Junkus, 2010, 89). Some important commodities that can be traded in both over-the-counter and organized commodity markets are shown in Table 1.

Amongst the mentioned commodities, petroleum from energy products and gold from precious metals come to the fore, more in terms of their effect on markets. These commodities are of a great interest to researchers and investors in terms of both high price levels and excessive volatility in prices. Crude oil prices affect almost all economic sectors (Abdullah, Saiti \& Masih, 2016, 219). Gold is seen as the leading investment instrument and the leading commodity on the metal markets. In addition, gold is seen as a reliable port in order to avoid excessive risk on financial markets and an important risk management tool in hedging and portfolio diversification since it is less sensitive to the exchange rate fluctuations (Hussin, Muhammad, Razak, Tha \& Marwan, 2013, 162). In fact, gold is an entity possessing the desired properties of money. This is because, unlike many other commodities, gold is durable, easily distinguishable, storable, portable and divisible and easily standardized (Baur, 2013, 5).

Islamic banks have a share of approximately $73 \%$ in the global Islamic finance sector. However, the general

Table 1 The types of commodities

\begin{tabular}{llllll}
\hline Energy Products & \multicolumn{1}{c}{$\begin{array}{c}\text { Precious } \\
\text { Metals }\end{array}$} & $\begin{array}{c}\text { Other Metals \& } \\
\text { Minerals }\end{array}$ & $\begin{array}{c}\text { Agricultural } \\
\text { Products }\end{array}$ & $\begin{array}{c}\text { Soft } \\
\text { Commodities / } \\
\text { Other Plants }\end{array}$ & $\begin{array}{c}\text { Animal } \\
\text { Products }\end{array}$ \\
\hline Brent oil & Gold & Aluminum & Wheat & Coffee & Livestock \\
Crude oil & Silver & Copper & Corn & Cocoa & Milk \\
Natural Gas & Platinum & Zinc & Cotton & Sugar & \\
Electric & Palladium & Lead & Potato & & \\
Kerosene & & Tin & Rice & & \\
Heating fuel & & & Orange juice & & \\
Carbon emissions & & & & & \\
\end{tabular}

Source: Koy, 2018, 23. 
trend in this field is shifting from banking to Islamic capital market instruments with higher growth rates. The most common of these instruments are Islamic stock indices and Islamic investment funds (Buğan, 2016, 250). In short, Islamic stock indices (Buğan, 2016, 251), which can be defined as the indices of the enterprises that meet the determined Islamic criteria, or participation indices with the name used in our country are one of the most important instruments of Islamic capital markets (Hussin et al, 2013, 167). The less risky nature of Islamic stock markets and the extraordinary growth rate of these indices increase demand for these indices and are considered as one of the biggest innovations in the financial field (Raza, Ibrahimy \& Ali, 2015, 4).

In general, Islamic indices (participation indices) must be in line with the Islamic criteria, unlike conventional indices. These criteria consist of the two stages: as the main activity area criteria and the financial criteria. According to the main activity area criteria, firms' main activities to be included in the index should only be in the areas deemed appropriate by Islam. In order to be able to enter the index according to financial criteria, companies should provide certain financial ratios calculated as Total Interest Loans/Market Value, Interest Income Cash and Securities/Market Value and Income from the Activities Specified in the First Criterion/Total Value (www.katilimendeksi.org). However, these criteria for Islamic indices are not completely standard for each country or each index calculator. The mentioned criteria may differ in terms of the determined values for the activity and the financial ratios (Derigs \& Marzban, 2008, 289; Buğan, 2016, 252-255).

The analysis of the linkages between commodities and Islamic capital markets attracts financial actors' attention, especially as commodities are included in many investment portfolios together with a raw material and stock classes (Khan \& Masih, 2014, 4). According to the ICD - Thomson Reuters (2017) Interest-Free Finance Development Report, the total assets of the global interest-free finance system grew by almost $10 \%$ compared to the previous year, having reached \$2.417 billion by the end of 2017 . According to the estimates, the total Islamic finance assets are anticipated to reach $\$ 3.8$ trillion by 2022 . This corresponds to an average annual growth of approximately $10 \%$. The total value of the capital market products in Islamic financial assets was determined to be $\$ 509$ billion by the end of 2017, and is expected to exceed US \$1 trillion by 2022 . Demonstrating the interaction between such a fastgrowing sector and commodity markets will enable the provision of important information to both investors and portfolio managers.

The first aim of this study is to determine whether the investors who invest in Islamic stock indices in Turkey can invest in gold or Brent oil for the purpose of their portfolio diversification. The other aim of the study is to determine whether Islamic stock index returns can be predicted by using the commodity market data. Thus, whether the Islamic markets operating on the basis of asset-based financing are related to commodity markets will be revealed.

In this context, the hypotheses of the study will be as follows:

H1: An investor investing the Participation-30 Islamic Stock Index in Turkey can invest in gold and Brent oil for the purpose of his portfolio diversification.

H2: Gold and Brent oil price data can be used to predict the Participation-30 Islamic Stock Index in Turkey.

H3: There is a relationship between Islamic markets and the commodity markets operating in accordance with the principle of asset-based financing.

In order to attain the goals of the study, long-term cointegration and the causality relationship between the Participation-30, as one of the Islamic stock indices in Turkey, on the one hand, and commodity markets, on the other, are being tested. The papers on this subject matter have been written in Far-East Asian countries such as Malaysia, which has developed Islamic markets, and in Gulf countries. However, the Turkey's example has not previously been seen in any paper. This situation reveals the specificity of the 
study. In terms of the method, the fact that it is the first study to be examining the relationship between the participation indices and commodity markets by using the Fourier form tests that take into account many transient structural breaks with smooth transition reveals yet another unique aspect of the study.

The study consists of five chapters. Following the introduction part, a review of the literature is given in the second section. In the third chapter, the scope and methods of the study are explained. After the findings have been presented in the fourth section, the results and the suggestions are given in the final section.

\section{LITERATURE REVIEW}

The relationship between commodity markets and stock markets has never lost its importance and has been included in a wide research area. In the literature, the relationships between oil and conventional stock returns have been researched more heavily than commodity markets (Jones \& Kaul, 1996; Sadorsky, 1999; Basher \& Sadorsky, 2006; Büyükşahin, Haigh \& Robe, 2008; Narayan \& Sharma, 2011; Fahami, Haris \& Mutalib, 2014). On the other hand, the relationships between the conventional stock market indices and the Islamic stock market indices have been studied in a significant number of studies in terms of portfolio diversification (Saiti, Bacha \& Masih, 2014; Nazlioglu, Hammoudeh \& Gupta, 2015; Bahloul, Mroua \& Naifar, 2017; Jebran, Chen \& Tauni, 2017). In this study, the relationships between commodity prices and Islamic indices are discussed. Previous studies of these relationships are presented in this part of the study.

The first studies to have been investigating the relationship between Islamic markets and commodity prices are those conducted by Hussin and his colleagues. M. Y. M. Hussin, F. Muhammad, K. Noordin, N. F. Marwan and A. A. Razak (2012a) focused on the impact of shocks in oil prices and macroeconomic variables on the Islamic stock market in Malaysia. In the study, the VAR model, the Johansen-Juselius Cointegration Test and the
VECM Granger Causality Test were applied to the January 2007 - December 2011 period. According to the findings, cointegration between the Islamic stock prices, the oil price and the selected macroeconomic variables was established. According to the Granger causality, no relation was found between the Islamic stock prices and the crude oil price.

M. Y. M. Hussin, F. Muhammad, M. F. Abu and A. A. Razak (2012b) investigated the relationship between the Islamic stock markets, the oil price and the macroeconomic variables for Malaysia. The VAR model, the Johansen-Juselius Cointegration Test and the Granger Causality Test were used in the study. As a result of the paper, the Islamic stock prices were seen as being cointegrated together with the exchange rate and the oil price variables. Based on the cointegration analysis, the Islamic stock price was positively and significantly correlated with the oil price variable. According to the Granger Causality Test Analysis, the oil price variable was the Granger cause of the Islamic stock market return in Malaysia.

Hussin et al (2013) investigated the relationship between the FTSE Bursa Malaysia Emas Shariah Index and strategic commodities (crude oil and Kijang gold). The study covered the January 2007 December 2011 period, and included the VAR model, the Johansen-Juselius Cointegration Test and the Granger Causality Test. According to the findings, no cointegration relationship was found between the FTSE Bursa Malaysia Emas Shariah Index and strategic commodities. Moreover, a two-way causality relationship between this index and crude oil prices was established, whereas no causality among the Kijang gold prices was found.

A. Khan and M. Masih (2014) investigated the relationships between energy indices, precious metals, agricultural products, non-ferrous metals and soft products spot indices with the Dow Jones Islamic Index. In addition, the Dow Jones Spot Commodity Index was included as the total commodity price index. The MGARCH-DCC model was used in the study covering the period from January 3, 2001 to March 28, 2013. According to the findings of the study, the relations between the commodity and the Islamic 
stock markets were seen to have developed over time and to have been quite variable, especially since the 2007-2008 global financial crisis. While an uncertain level of speculation was highlighted for the energy sector (oil), the safe haven role of the precious metal (gold) sector was proven.

The main purpose of the study conducted by S. H. M. Rithuan, A. M. Abdullah and A. M. M. Masih (2014) was the examination of the causal nexus between the crude oil price and the Islamic Stock Index in the Gulf Cooperation Council member countries (the UAE, S. Arabia, Qatar, Kuwait, Bahrain and Oman). The prices of the other commodities, such as corn and gold prices, were also included in the study as the control variables and the robustness tests. According to the results of the study, cointegration between the Islamic stock indices and commodities was identified by applying the Vector Error Correction Model (VECM), the Johansen Cointegration Test and the Wavelet (Wavelet) Approach. The Islamic stock indices and the crude oil prices in Saudi Arabia and Oman were found to lead to the other Islamic stock indices and commodities. According to the Discrete Wavelet Transform (MODWT) technique, the crude oil price leads to the other Islamic indices in the short run. According to the Continuous Wavelet Transform (CWT) technique, if the investor's investment period is less than 128 days, they will benefit from portfolio diversification.

T. Chebbi and A. Derbali (2015) investigated the links between Islamic capital markets (the QE Al Rayan Islamic Index) and strategic commodities (crude oil and natural gas). The GARCH-DCC method was used in the study and the results showed that the volatility in commodity returns was strongly related to the $\mathrm{QE}$ Al-Rayan Islamic Index, and this result affected the financialization of commodity markets.

While investigating the role of safe-haven assets in the fields of time and frequency, N. Raza, A. Ibrahimy and A. B. Ali (2015) compared gold and the Dow Jones Islamic World Emerging Market Index for two different crisis periods. Kao Panel Cointegration Tests, the Pooled Mean Group (PMG) Estimator, and the Wavelet Approach were applied in the study. According to the findings, the Islamic emerging markets and the BRICS stock markets were cointegrated and gold would be the portfolio diversifier of the Islamic stock markets.

The main purpose of the study conducted by A. M. Abdullah, B. Saiti and M. Masih (2016) was to investigate the dynamic causal relationship between commodity prices (crude oil, corn and gold) and the Islamic Stock Indices in Southeast Asian countries (Singapore, Philippines, Indonesia, Thailand and Malaysia). Gold and corn prices were included in the study as the control variables and the robustness tests. In the study, the Johansen Cointegration Test, the VECM-Granger Causality Test, the Wavelet Technique (MODWT and CWT), and the MGARCHDCC model were applied. According to the findings, the Islamic stock indices and the commodity prices in the Southeast Asian countries were moving together in the long run. The Malaysian Islamic stock market indices had the lowest volatility.

M. K. Nejad, F. Jahantigh and H. Rahbari (2016) investigated the relationship between the oil price risk and the Tehran stock return for the January 2003-October 2014 period. The Gregory-Hansen, Saikkonen-Lütkepohl and Johansen-Juselius Cointegration Tests were done and a long-term relationship between Tehran Stock Index and the oil price was found.

In their study, K. M. Kisswani and M. I. Elian (2017) used the non-linear ARDL (NARDL), the JohansenJuselius Cointegration Test, the Error Correction Model and the Granger Causality Tests to investigate the relationship between the Kuwait Stock Market (10 main sectors) and oil prices (West Texas and Brent). According to the study's findings, the oil prices and some Kuwaiti sectoral stock prices showed asymmetric long-term effects. In addition, while the empirical results for these sectors demonstrated a short-term asymmetric effect in the case of the WTI price measure, no evidence of an asymmetric effect was found, but there was a symmetric effect in the case of the price of Brent oil.

The studies mentioned are summarized in Table 2. 
Table 2 The literature review

\begin{tabular}{|c|c|c|c|c|c|c|}
\hline \multirow{2}{*}{ Source } & \multirow{2}{*}{$\begin{array}{c}\text { Data } \\
\text { (Frequency) }\end{array}$} & \multicolumn{2}{|c|}{ Variables } & \multirow{2}{*}{ Econometric Method } & \multicolumn{2}{|c|}{ Empirical findings } \\
\hline & & Stock exchange & Commodity & & Cointegration & Causality \\
\hline $\begin{array}{l}\text { Hussin et al, } \\
(2012 a)\end{array}$ & $\begin{array}{l}\text { January } 2007 \text { - } \\
\text { December } 2011 \\
\text { (Monthly) }\end{array}$ & $\begin{array}{l}\text { FTSE Bursa } \\
\text { Malaysia Emas } \\
\text { Shariah Index }\end{array}$ & Crude Oil & $\begin{array}{l}\text { Johansen-Juselius } \\
\text { cointegration test } \\
\text { VECM Granger causality } \\
\text { test }\end{array}$ & $=$ & No relationship \\
\hline $\begin{array}{l}\text { Hussin et al, } \\
(2012 b)\end{array}$ & $\begin{array}{l}\text { January } 2007 \text { - } \\
\text { December } 2011 \\
\text { (Monthly) }\end{array}$ & $\begin{array}{l}\text { FTSE Bursa } \\
\text { Malaysia Emas } \\
\text { Shariah Index }\end{array}$ & Crude Oil & $\begin{array}{l}\text { Johansen-Juselius } \\
\text { cointegration test } \\
\text { Granger causality test }\end{array}$ & $=$ & $\mathrm{EP} \rightarrow \mathrm{ISP}$ \\
\hline $\begin{array}{l}\text { Hussin et al, } \\
(2013)\end{array}$ & $\begin{array}{l}\text { January } 2007 \text { - } \\
\text { December } 2011 \\
\text { (Monthly) }\end{array}$ & $\begin{array}{l}\text { FTSE Bursa } \\
\text { Malaysia Emas } \\
\text { Shariah Index }\end{array}$ & $\begin{array}{l}\text { Crude Oil } \\
\text { Kijang Gold }\end{array}$ & $\begin{array}{l}\text { Johansen-Juselius } \\
\text { cointegration test } \\
\text { Granger causality test }\end{array}$ & $\neq$ & $\begin{array}{l}\mathrm{ISP} \leftrightarrow \mathrm{EP} \\
\text { (Petrol) }\end{array}$ \\
\hline $\begin{array}{l}\text { Khan and Masih } \\
\text { (2014) }\end{array}$ & $\begin{array}{l}03.01 .2001- \\
28.03 .2013 \\
\text { (Daily) }\end{array}$ & $\begin{array}{l}\text { DJ Islamic Price } \\
\text { Index }\end{array}$ & $\begin{array}{l}\text { DJ } \\
\text { Commodity } \\
\text { Indices }\end{array}$ & MGARCH-DCC & $\begin{array}{l}\text { This analysis } \\
\text { has not been } \\
\text { conducted. }\end{array}$ & $\begin{array}{l}\text { This analysis } \\
\text { has not been } \\
\text { conducted. }\end{array}$ \\
\hline $\begin{array}{l}\text { Rithuan, Abdullah } \\
\text { and Masih (2014) }\end{array}$ & $\begin{array}{l}01.01 .2000- \\
28.02 .2014 \\
\text { (Daily) }\end{array}$ & $\begin{array}{l}\text { Gulf Cooperation } \\
\text { Council Members } \\
\text { Islamic Markets }\end{array}$ & $\begin{array}{l}\text { Crude Oil } \\
\text { Gold } \\
\text { Corn }\end{array}$ & $\begin{array}{l}\text { Johansen cointegration } \\
\text { test, } \\
\text { Wavelet approaches } \\
\text { (MODWT and CWT) }\end{array}$ & $=$ & $\begin{array}{l}\text { ISP (S. Arabia and } \\
\text { Oman) and EP } \\
\text { (Petroleum) } \rightarrow \\
\text { Other ISP and EP }\end{array}$ \\
\hline $\begin{array}{l}\text { Chebbi and Derbali } \\
\text { (2015) }\end{array}$ & $\begin{array}{l}15.03 .2011 \\
-25.12 .2014 \\
\text { (Daily) }\end{array}$ & $\begin{array}{l}\text { Qe Al Rayan } \\
\text { Islamic Index }\end{array}$ & $\begin{array}{l}\text { Crude Oil } \\
\text { Natural Gas }\end{array}$ & GARCH-DCC & $\begin{array}{l}\text { This analysis } \\
\text { has not been } \\
\text { conducted. }\end{array}$ & $\begin{array}{l}\text { This analysis } \\
\text { has not been } \\
\text { conducted. }\end{array}$ \\
\hline $\begin{array}{l}\text { Raza, Ibrahimy and } \\
\text { Ali (2015) }\end{array}$ & $\begin{array}{l}01.01 .1996 \\
-31.12 .2014 \\
\text { (Daily) }\end{array}$ & $\begin{array}{l}\text { DJ Islamic World } \\
\text { Emerging Market } \\
\text { Index, BRICS } \\
\text { Commodity } \\
\text { Exchanges }\end{array}$ & Gold & $\begin{array}{l}\text { Kao Panel cointegration } \\
\text { tests } \\
\text { Wavelet approach }\end{array}$ & $=$ & $\begin{array}{l}\text { This analysis } \\
\text { has not been } \\
\text { conducted. }\end{array}$ \\
\hline $\begin{array}{l}\text { Abdullah, Saiti and } \\
\text { Masih } \\
(2016)\end{array}$ & $\begin{array}{l}\text { 01.06.2007- } \\
28.02 .2014 \\
\text { (Daily) }\end{array}$ & $\begin{array}{l}\text { Southeast Asian } \\
\text { Islamic Stock } \\
\text { Markets }\end{array}$ & $\begin{array}{l}\text { Crude Oil } \\
\text { Gold } \\
\text { Corn }\end{array}$ & $\begin{array}{l}\text { Johansen cointegration } \\
\text { test, Granger causality } \\
\text { test, Wavelet approaches } \\
\text { (MODWT and CWT), } \\
\text { MGARCH-DCC method }\end{array}$ & $=$ & $\begin{array}{l}\text { EP } \rightarrow \text { ISP } \\
\text { (Singapore, } \\
\text { Philippines and } \\
\text { Thailand) }\end{array}$ \\
\hline $\begin{array}{l}\text { Nejad, Jahantigh } \\
\text { and Rahbari (2016) }\end{array}$ & $\begin{array}{l}\text { January } \\
\text { 2003-October } \\
2014 \text { (Daily) }\end{array}$ & $\begin{array}{l}\text { Tehran Stock } \\
\text { Market }\end{array}$ & $\begin{array}{l}\text { OPEC Oil } \\
\text { Basket }\end{array}$ & $\begin{array}{l}\text { Cointegration tests (GH, } \\
\text { Saikkonen-Lütkepohl and } \\
\text { Johansen) }\end{array}$ & $=$ & $\begin{array}{l}\text { This analysis } \\
\text { has not been } \\
\text { conducted. }\end{array}$ \\
\hline $\begin{array}{l}\text { Kisswani and Elian } \\
\text { (2017) }\end{array}$ & $\begin{array}{l}03.01 .2000- \\
09.11 .2015 \\
\text { (Daily) }\end{array}$ & $\begin{array}{l}\text { Kuwait Stock } \\
\text { Exchange (10 Main } \\
\text { Sector) }\end{array}$ & Crude Oil & $\begin{array}{l}\text { N-ARDL } \\
\text { Granger causality tests }\end{array}$ & $=$ & $\begin{array}{l}\text { There are } \\
\text { different results } \\
\text { according to the } \\
\text { sector. }\end{array}$ \\
\hline
\end{tabular}

Note: ISP represents Islamic stock prices and EP represents commodity prices. In addition, " $\rightarrow$ " sign indicates one-way causality relationship, " $\leftrightarrow$ " sign indicates two-way causality relationship, "=" sign indicates cointegration relationship, and " $\neq$ "sign indicates that there is no cointegration.

Source: Authors 
According to the report presented in Table 2, the studies of commodity markets and Islamic markets or Islamic indices are quite limited. In addition, there is almost no study regarding this issue in Turkey. In this context, the fact that it is the first study to examine these relations in Turkish markets reveals the originality of the paper. Almost all of the studies have identified the cointegration relationship between commodity markets and Islamic markets or Islamic indices. The findings of causality were found to vary according to the country and the indices examined.

\section{ECONOMETRIC METHODOLOGY}

Structural changes are very important in a time series analysis. Structural improvements in time series can be caused for various reasons, such as economic crises, wars and political changes. The important issue at this point is that the structural changes cannot be determined by conventional econometric methods. For example, serious structural changes in time series are ignored when the ADF, the PP and the KPSS Unit Roots, the Johansen Cointegration, Granger and TodaYamamoto causality tests are applied. This situation may lead to false or inaccurate findings (Çil Yavuz, 2015, 308).

In this context, the literature shows us that both the unit root and the cointegration applications that take structural breaks into consideration are used. Thus, serious structural changes in data will not be overlooked. However, the disadvantage of these tests reflects in their not being capable of accounting for a large number of smooth-transition structural breaks. The authors identified shortcomings in the literature, and developed the Fourier unit root, cointegration and causality tests (Becker, Enders \& Lee, 2006; Enders and Jones, 2015; Tsong, Lee, Tsai \& Hu, 2015).

A Fourier series is an expansion of a periodic $y_{t}$ function in the form of an infinite sum of cosines and sinuses. The Fourier KPSS tests developed by $\mathrm{R}$. Becker et al (2006) use trigonometric functions to capture changes larger than the mean of the dependent variable. The advantage of this test is that it takes into account many smooth-transition structural breaks with smooth transition. The econometric model of this test, which is the Fourier extension of the KPSS (1992) Unit Root Test, can be explained in the following manner:

$$
y_{t}=\lambda_{0}+\lambda_{1} \sin \left(\frac{2 \pi k t}{T}\right)+\lambda_{2} \cos \left(\frac{2 \pi k t}{T}\right)+v_{t}
$$

where $T$ represents the sample size, $\lambda_{1}$ and $\lambda_{2}$ are the Fourier coefficients, $\pi$ is 3.11416, and $k$ is the frequency used to find the optimal value that makes the sum of the residual squares the smallest.

In order to carry out this test, it is first necessary that $k$, which is the total of the smallest residual squares, should be determined. After determining the appropriate frequency $(k)$, whether the F statistic obtained from this model is meaningful or not is decided by making comparisons with the critical values given by R. Becker et al (2006). In the final stage, the residual series of the selected model $\mathrm{k}$ is created and the traditional KPSS test is applied to the residual series of the series. In this way, the Fourier KPSS test is performed. According to this test, the null hypothesis indicates that the series is stationary and the alternative hypothesis indicates the existence of the unit root in the series (Beşel \& Uygun, 2017).

The second method used in the study is the Fourier Cointegration Test developed by C. C. Tsong et al (2015). This method uses the same mathematical structure as the FKPSS Unit Root Test. In this context, in the absence of the independent variable and the Fourier function, the results of the FKPSS Unit Root Test are obtained. In the absence of the Fourier function when there is an independent variable, the results of the $\mathrm{Y}$. Shin (1994) Cointegration Test will appear. According to the test, the null hypothesis indicates the existence of cointegration and the alternative hypothesis shows that there is no cointegration (Y1lanc1, Aslan \& Özgür, 2017).

The last method used in the study was the Fourier Causality Test developed by W. Enders and P. Jones (2015). As the name implies, this test is the Fourier form of the traditional Granger Causality Test. While 
almost all of the causality tests in the literature fail to take into account structural breaks, this method takes such structural breaks into consideration in a smooth transition form. This test also operates in the same econometric logic as the Fourier Unit Root and the Fourier Cointegration Tests. The difference between the Fourier methods used in the study is in terms of the hypotheses. The null hypothesis indicates that there is no causality between the series, whereas the alternative hypothesis indicates the existence of such causality.

\section{DATA AND EMPIRICAL FINDINGS}

\section{Data}

The Participation-30 Index, which has the longest time interval amongst the Islamic indices in Turkey, was used in the study as a data set representing the Islamic indices, whereas the other variables were the Brent oil price expressed in dollars per barrel and the gold ounce as the basis of dollars. As can be seen in the literature in Table 2, oil and gold were generally used to represent the commodity variable. Therefore, the commodities mentioned in the literature were preferred in this study.

The data set ranges between $7^{\text {th }}$ Jan. 2011 and $4^{\text {th }}$ June 2018, on a daily basis. When the studies in the literature are examined, it is determined that the observation frequency is mostly used on a daily basis. The data for the Participation-30 Index were obtained from the Foreks website (www.foreks.com), the Brent oil data were available on the US Energy Information Management's website (www.eia.gov), whereas the gold ounce basis data were obtained from the World Gold Council's website (www.gold.org). In order to keep the data range broad, the other İstanbul Stock Market (Borsa Istanbul) Islamic Indices, the Participation-50 and the Participation Model Portfolio, whose historical data reach back in the year 2014, were not included in the study.

The logarithmic transformations of the series data were taken so as to prevent return volatility prior to performing the analysis. Moreover, during the Fourier Causality Tests, the findings were obtained by a 10,000 Monte Carlo Bootstrap Simulation.

The logarithmic time series graphs in the data ranges studied for the Participation-30, Brent Oil and Golden Ounce series are presented below (Figures 1, 2 and 3).

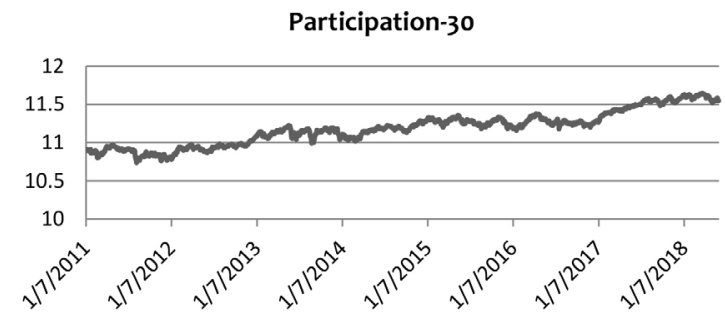

Figure 1 Participation-30 Index (Logarithmic)

Source: Authors

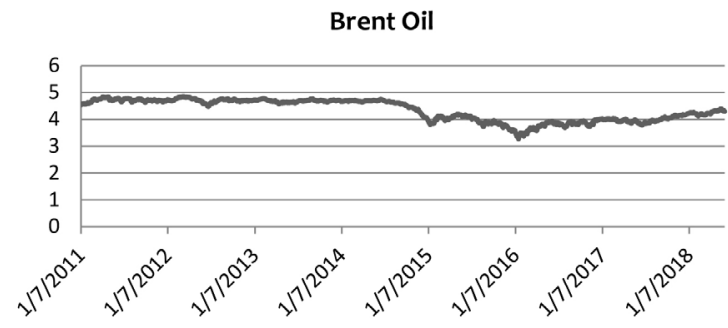

Figure 2 Brent Oil (Logarithmic)

Source: Authors

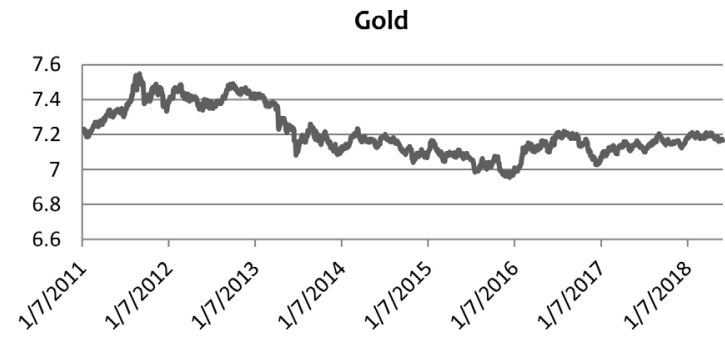

Figure 3 Gold Ounce (Logarithmic)

Source: Authors 


\section{Empirical Findings}

Following the disclosure of the data used, the first procedure is to determine the stationary order of the series. According to the results in Table 3, it is seen that all the three indices have the unit roots in the level forms and become stable as a result of the first difference-taking process. Because the level-value test statistics are higher than the critical values in R. Becker et al (2006), the test statistics obtained as a result of the first difference are lower than those critical ones.

Table 3 The Fourier KPSS Unit Root Test results

\begin{tabular}{l|ccc}
\hline Variables & $\mathrm{F}(\mathrm{k})$ & Level & $1^{\text {st }}$ Difference \\
\hline Participation-30 & 3 & 5.00 & $0.014^{* * *}$ \\
Brent Oil & 1 & 4.64 & $0.029^{* * *}$ \\
Gold Ounce & 1 & 3.49 & $0.014^{* * *}$ \\
\hline
\end{tabular}

Note: The critical values were obtained from R. Becker et al (2006).

Source: Authors

It would be appropriate to investigate the cointegration relationship in such a case where the series are stationary in the first differences. The results of the Fourier SHIN Cointegration Test performed in this context are accounted for in Table 4. The H1 hypothesis, which indicates that there is no cointegration relationship for both matches, is accepted. In this context, an investor investing in the Participation-30 Index can invest in gold or Brent oil while diversifying its portfolio in order to reduce its risk.

Following the analysis of the unit root and the cointegration tests in the Fourier form, the causality test in the Fourier form is appropriate to use. According to the results of the Fourier Causality Test presented in Table 5 and developed by W. Enders and P. Jones (2015), no evidence of causality was found.
Table 4 The Fourier SHIN Cointegration Test results

\begin{tabular}{l|cccc}
\hline & MinSSR & $\mathrm{F}(\mathrm{k})$ & $\mathrm{Fm}(\mathrm{k})$ & $\mathrm{Tm}(\mathrm{k})$ \\
\hline $\begin{array}{l}\text { Cold Ounce and } \\
\text { Participation-30 }\end{array}$ & 19.98 & 2 & 14.80 & 0.67 \\
$\begin{array}{l}\text { Brent Oil and } \\
\text { Participation-30 }\end{array}$ & 38.91 & 3 & 3.55 & 2.39 \\
\hline
\end{tabular}

Note: The critical values for the Participation-30 and the gold ounce mapping were $0.078,0.099$ and 0.163 , at the level of significance of $\% 1,5$ and 10 , respectively. The critical values for the Participation-30 and the Brent oil mapping were $0.090,0.114$ and 0.170 at the level of significance $\% 1,5$ and 10 , respectively. These values were obtained from C. C. Tsong et al (2015).

Source: Authors

Table 5 The Fourier Granger Causality Test results

\begin{tabular}{|c|c|c|c|}
\hline The Direction of Causality & $\begin{array}{c}\text { Wald } \\
\text { Statistics }\end{array}$ & $\begin{array}{c}\text { Asymptoti } \\
\text { p-value }\end{array}$ & $\begin{array}{c}\text { Bootstrap } \\
\text { p-value }\end{array}$ \\
\hline Participation-30 $\rightarrow$ Brent Oil & 0.068 & 0.795 & 0.800 \\
\hline Brent Oil $\rightarrow$ Participation-30 & 1.239 & 0.266 & 0.263 \\
\hline $\begin{array}{c}\text { Participation-30 } \rightarrow \text { Gold } \\
\text { Ounce }\end{array}$ & 2.679 & 0.102 & 0.103 \\
\hline $\begin{array}{l}\text { Gold Ounce } \rightarrow \\
\text { Participation-30 }\end{array}$ & 1.340 & 0.246 & 0.236 \\
\hline
\end{tabular}

Source: Authors

\section{CONCLUSION}

The commodity market is the largest non-financial market in the world affecting a significant part of the world economy. The fact that the stock market performance can be affected by commodity markets makes the relationship between commodity markets and stock markets important. In addition to the other macroeconomic variables, commodity prices have 
been bearing special importance to the Islamic stock indices or the participation indices in our country in recent years because Islamic finance is a financial system based on the profit/loss sharing principle and is supportive of the activities carried out in the real sector in particular.

In this study, long-term cointegration and the causality relationships between the Islamic indices and the commodity markets in our country were investigated. Financial cointegration reveals the long-term relationships of the variables and provides investors with important pieces of information for their portfolio diversification. By means of the causality tests, the important other financial assets or market data forecasting clues are possible to obtain from a particular financial asset or market data. The daily data covering the period between $7^{\text {th }}$ Jan. 2011 and $4^{\text {th }}$ June 2018 were used in the study. In terms of the methodology, the relationship between the Participation-30 Index and commodity markets was examined by performing the Fourier form tests. In this context, the stability structures of the time series were examined through the Fourier KPSS Unit Root Test; the long-term relationships between the variables were investigated by applying the Fourier SHIN Cointegration Test, whereas the causality relations between the variables were examined by doing the Fourier Granger Causality Test.

According to the Fourier KPSS Unit Root Test used in the study, all of the three series (the Participation-30, Brent Oil and Ounce Gold) evidently have the unit roots in the level values and become stable as a result of the first difference-taking process. According to the Fourier SHIN Cointegration Test results, there is no long-term relationship between the Participation-30 Index and the ounce gold and Brent oil. In other words, an investor investing in the Participation-30 Index will be able to invest in gold or Brent oil while diversifying its portfolio in order to reduce its risk because an investor can diversify its portfolio by investing in the financial assets that do not act together in the long run. According to these results, the H1 hypothesis, assuming a portfolio diversification benefit amongst the variables, is accepted. The Fourier Granger Causality Test indicates no causality relationship to have been found between the Participation-30 Index and the ounce gold and Brent oil commodities. Thus, these variables will not be used together in making revenue estimates among financial assets. According to these results, the $\mathrm{H} 2$ and $\mathrm{H} 3$ hypotheses, assuming a relationship between the variables, are rejected. The results obtained by the Fourier SHIN Cointegration Test were compatible with Hussin et al (2013). On the other hand, the results obtained by the Fourier Granger Causality Test were in line with Hussin et al (2012a) and Hussin et al (2013) only for the gold ounce.

The study's most important result is that an investor investing in the Participation-30 Islamic Stock Indices in Turkey will be able to invest gold and Brent oil for his portfolio diversification. Another important result of the study is that, although the gold and the oil commodity markets are the world's largest nonfinancial markets, there is no causal relationship between the Islamic markets operating in the context of asset-based financing and the commodities mentioned. Thus, the gold and Brent oil price data cannot be used in the prediction of the Islamic Participation-30 Stock Index in Turkey.

There are several limitations of this study. First, as Islamic markets, especially so the Islamic Stock Indices, are relatively new in Turkey, the number of the observations that can be used in analysis is limited. On the other hand, the fact that the market is still very new also raises the question of the effectiveness of the market. For this reason, similar studies can be done again in subsequent periods, when these restrictions have been eliminated. Moreover, the relationship between the two other indices in our country (the Participation-50 and the Participation Model Portfolio) or the international Islamic indices and other commodities other than gold and Brent oil or international commodity indices can be investigated in future studies. In addition, the causality test performed in this study is related to causality in the mean. Future studies, however, may generate important pieces of information about the analysis of causality in variance or causality in frequency tests. 


\section{REFERENCES}

Abdullah, A. M., Saiti, B., \& Masih, M. (2016). The impact of crude oil price on islamic stock indices of South East Asian countries: Evidence from MGARCH-DCC and wavelet approaches. Borsa Istanbul Review, 16(4), 219-232. doi. org/10.1016/j.bir.2015.12.002

Bahloul, S., Mroua, M., \& Naifar, N. (2017). The impact of macroeconomic and conventional stock market variables on islamic index returns under regime switching. Borsa İstanbul Review, 17(1), 62-74. doi.org/10.1016/j.bir.2016.09.003

Basher, A. S., \& Sardorsky, P. (2006). Oil price risk and emerging stock markets. Global Finance Journal, 17(2), 224251. doi.org/10.1016/j.gfj.2006.04.001

Baur, D. (2013). Gold - Fundamental drivers and asset allocation. Retrieved May 20, 2018, from https://www.tdr.wiwi.uni-due. de/fileadmin/fileupload/VWL-WIPO/WiWi-Kolloquium/ Baur_Paper.pdf

Becker, R., Enders, W., \& Lee, J. (2006). A stationarity test in the presence of an unknown number of smooth breaks. Journal of Time Series Analysis, 27(3), 381-409. doi.org/10.1111/ j.1467-9892.2006.00478.x

Beşel, F., \& Uygun, U. (2017, October). The relationship between economic growth and tourism income: The case of Turkey. Paper presented na the 3rd SCF International Conference on Economic and Social Impacts of Globalization. Antalya, Turkey, 5-7.

Buğan, M. F. (2016). İslami hisse senedi endeksleri. In S. Erdoğan, A. Gedikli, \& D. Ç. Yıldırım (Eds.). İslam Ekonomisi ve Finansı (pp. 249-271). Kocaeli, Turkey: Umuttepe Yayınları.

Büyükşahin, B., Haigh, M. S., \& Robe, M. A. (2008). Commodities and equities: A "market of one". Retrieved May 30, 2018, from https://www.cftc.gov/sites/default/files/idc/groups/public/@ aboutcftc/documents/file/amarketofone_update0608.pdf.

Chebbi, T., \& Derbali, A. (2015). The dynamic correlation between energy commodities and Islamic stock market: Analysis and forecasting. International Journal of Trade and Global Markets, 8(2), 112-126. do1:10.1504/ijtgm.2015.069425

Çil Yavuz, N. (2015). Finansal Ekonometri. İstanbul, Turkey: Der Yayınları.
Derigs, U., \& Marzban, S. (2008). Review and analysis of current shariah-compliant equity screening practices. International Journal of Islamic and Middle Eastern Finance and Management, 1(4), 285-303. doi.org/10.1108/17538390810919600

Doyle, E., Hill, J., \& Jack, I. (2007). Growth in Commodity Investment: Risk and Challenges for Commodity Market Participants. London, UK: Financial Service Authority.

Enders, W., \& Jones, P. (2015). Grain prices, oil prices, and multiple smooth breaks in a VAR. Studies on Nonlinear Dynamics and Econometrics, 20(4), 399-419. doi.org/10.1515/ snde-2014- 0101.

Fahami, N. A., Haris, S., \& Mutalib, H. A. (2014). An econometric analysis between commodities and financial variables: The case of southeast Asia countries. International Journal of Business and Social Science, 5(7), 216-223.

Hussin, M. Y. M., Muhammad, F., Noordin, K., Marwan, N. F., \& Razak, A. A. (2012a). The impact of oil price shocks on Islamic financial market in Malaysia. Labuan e-Journal of Muamalat and Society, 6, 1-13.

Hussin, M. Y. M., Muhammad, F., Abu, M. F., \& Razak, A. A. (2012b). The relationship between oil price, exchange rate and Islamic stock market in Malaysia. Research Journal of Finance and Accounting, 3(5), 83-93.

Hussin, M. Y. M., Muhammad, F., Razak, A. A., Tha, G. P., \& Marwan, N. (2013). The link between gold price, oil price and Islamic stock market: Experience from Malaysia. Journal of Studies in Social Sciences, 4(2), 161-182.

ICD - Thomson Reuters. (2017). Islamic Finance Development Report 2017: Towards Sustainability. ICD-Thomson Reuters.

Jebran, K., Chen, S., \& Tauni, M. Z. (2017). Islamic and conventional equity index co-movement and volatility transmission: Evidence from Pakistan. Future Business Journal, 3(2), 98-106. doi.org/10.1016/j.fbj.2017.05.001

Jones, C. M., \& Kaul, G. (1996). Oil and the stock markets. The Journal of Finance, 51(2), 463-491. dor:10.2307/2329368

Junkus, J. C. (2010). Agricultural and metallurgical derivatives: Speculation and hedging. In R. W. Kolb, \& J. A. Overdahl (Eds.). Financial Derivatives: Pricing and Risk Management (pp. 77-87). New Jersey, USA: The Robert W. Kolb Series in Finance, JohnWiley \& Sons Inc. 89-101. 
Khan, A., \& Masih, M. (2014). Correlation between Islamic stock and commodity markets: An investigation into the impact of financial crisis and financialization of commodity markets. MPRA Paper No. 56979, Munich Personal RePEc Archive.

Kisswani, K. M., \& Elian, M. I. (2017). Exploring the nexus between oil prices and sectoral stock prices: Nonlinear evidence from Kuwait stock exchange. Cogent Economics \& Finance, 5(1), 1-17. doi.org/10.1080/23322039.2017.1286061

Koy, A. (2018). Türev Piyasalar: Emtia Türevleri, Opsiyonlar Vadeli İşlem Sözleşmeleri. Ankara, Turkey: Seçkin Yayıncılık.

Narayan, P. K., \& Sharma, S. S. (2011). New evidence on oil price and firm returns. Journal of Banking \& Finance, 35(12), 3253-3262. doi.org/10.1016/j.jbankfin.2011.05.010

Nazlioglu, S., Hammoudeh, S., \& Gupta, R. (2015). Volatility transmission between Islamic and conventional equity markets: Evidence from causality-in-variance test. Applied Economics, 47(46), 4996-5011. dor:10.1080/00036846.2015.1039 705

Nejad, M. K., Jahantigh, F., \& Rahbari, H. (2016). The long run relationship between oil price risk and Tehran stock exchange returns in presence of structural breaks. Procedia Economics and Finance, 36, 201-209. doi.org/10.1016/S22125671(16)30031-4

Raza, N., Ibrahimy, A., \& Ali, A. B. (2015). Gold and Islamic stocks a hedge and safe haven comparison in time and frequency domain for BRICS markets. Proceedings of the Asia Pacific Conference on Business and Social Sciences, Kuala Lumpur, Malaysia: MPRA Paper No. 69366.
Rithuan, S. H. M., Abdullah, A. M., \& Masih, A. M. M. (2014). The impact of crude oil price on Islamic stock indices of gulf cooperation council (GCC) countries: A comparative analysis. MPRA Paper No. 56989.

Sadorsky, P. (1999). Oil price shocks and stock market activity. Energy Economics, 21(5), 449-469. doi.org/10.1016/S01409883(99)00020-1

Saiti, B., Bacha, O. I., \& Masih, M. (2014). The diversification benefits from Islamic investment during the financial turmoil: The case for the US-based equity investors. Borsa İstanbul Review, 14(4), 196-211. doi.org/10.1016/j. bir.2014.08.002

Shin, Y. (1994). A residual-based test of the null of cointegration against the alternative of no cointegration. Econometric Theory, 10(1), 91-115. doi.org/10.1017/S0266466600008240

Tsong, C. C., Lee, C. F., Tsai, L. J., \& Hu, T. C. (2015). The Fourier approximation and testing for the null of cointegration. Empirical Economics, 51(3), 1085-1113. doi:10.1007/s00181-0151028-6

Yılancı, V., Aslan, M., \& Özgür, Ö. (2017). Testing the validity of PPP theory for African countries. Applied Economics Letters, 25(18), 1273-1277. doi.org/10.1080/13504851.2017.1418 066

FOREKS. https://www.foreks.com

KATILIM ENDEKSI. http://www.katilimendeksi.org

U.S. Energy Information Administration. https://www.eia.gov World Gold Council. https://www.gold.org

Received on $27^{\text {th }}$ October 2018, after revision, accepted for publication on $12^{\text {th }}$ December 2018 Published online on $28^{\text {th }}$ December 2018 
Şakir Sakarya is a professor at the Faculty of Economics and Administrative Sciences, Balıkesir University, Balıkesir, Republic of Turkey, as well as the Vice President of Balıkesir University. His main research areas include financial markets and institutions, investments and portfolio management, financial forecasting and modeling.

Feyyaz Zeren is an associate professor at the Faculty of Economics and Administrative Sciences, Yalova University, Yalova, Republic of Turkey. His main research areas include financial markets and institutions, investments and portfolio management, time series and panel data models in finance.

Hilmi Tunahan Akkuş is a lecturer at Savaştepe Vocational School, Balıkesir University, Balıkesir, Republic of Turkey, as well as an assistant director in Savaştepe Vocational School. His main research areas include Islamic finance, financial markets and institutions, investments and portfolio management, financial forecasting and modeling. 


\title{
THE RELATIONSHIP BETWEEN ISLAMIC INDICES AND COMMODITY MARKETS IN TURKEY: EVIDENCE FOURIER-BASED APPROACHES
}

\author{
Şakir Sakarya', Feyyaz Zeren ${ }^{*_{2}}$ and Hilmi Tunahan Akkuş ${ }^{1}$ \\ 'Department of Business Administration, Balıkesir University, Balıkesir, Turkey \\ ${ }^{2}$ Department of International Trade and Finance, Yalova University, Yalova, Turkey
}

\begin{abstract}
Affecting a significant portion of the world economy, the commodity market is the world's largest "nonfinancial" market. In addition to the other macroeconomic variables, commodity prices have a special importance for Islamic stock indices, which have improved in recent years because Islamic finance is a financial system based on the profit/loss sharing principle and supports the real sector's activities. In this study, cointegration and the causality relationship between commodity markets (the Gold ounce and Brent oil) and the Participation-30 Index established by taking Islamic criteria into account were investigated in Turkey. As a result of the analysis, no cointegration relation was found between the Participation-30 Index and the commodity markets. According to these results, an investor investing in gold or oil will, in addition to the Participation-30 Index, diversify its portfolio with this commodity investment and minimize its risk. The fact that there is no relation between the variables according to the causality results indicates that the Participation-30 Islamic Indices' structure is independent of commodity markets and conventional stock markets.
\end{abstract}

Keywords: Participation-30 Islamic Indices, commodity markets, Fourier-based approaches, portfolio diversification

\section{JEL Classification: G11, G15}

\section{INTRODUCTION}

The fact that the stock market performance can be affected by commodity markets makes the relationship between commodity markets and stock markets significant. In addition to the other

* Correspondence to: F. Zeren, Department of International Trade and Finance, Yalova University, Yalova, Turkey; e-mail: feyyaz.zeren@yalova.edu.tr macroeconomic variables, commodity prices have a special importance for Islamic stock indices, which have improved in recent years because Islamic finance is a financial system based on the profit/loss sharing principle and is especially supportive of the real sector's activities. In addition, the quantitative criteria needed in the formation of Islamic stock indices require that some ratios related to liquidity, interest rates, indebtedness and undesirable gains should be 
provided. This situation may force the enterprises included in the index to turn to real markets. Therefore, the relationship between Islamic indices and commodity markets is expected and considered to be important.

After the dot.com bubble burst in 2000, i.e. the collapse of high-tech companies' (mainly Internet companies') shares, commodity prices and commodity investment levels increased significantly. Commodity markets enable investors to benefit more from the commodity markets that have a negative price relationship with bonds and stocks in order to diversify their portfolios and also provide investors with the return they seek (Doyle, Hill \& Jack, 2007, 5).

Apart from the low returns obtained from bonds and volatile stock markets, what can make commodity markets advantageous in terms of their attracting investors and preserving the existing investment is a negative correlation between commodities and bonds and stocks, on the one hand, and a positive correlation between commodities and inflation (Doyle et al, 2007, 45). Commodity markets affect an important part of the world economy and are considered to be the world's largest "nonfinancial" market (Doyle et al, 2007, 15; Junkus, 2010, 89). Each one of the commodities in these markets includes a wide range of products with specific demand and supply fundamentals
(Junkus, 2010, 89). Some important commodities that can be traded in both over-the-counter and organized commodity markets are shown in Table 1.

Amongst the mentioned commodities, petroleum from energy products and gold from precious metals come to the fore, more in terms of their effect on markets. These commodities are of a great interest to researchers and investors in terms of both high price levels and excessive volatility in prices. Crude oil prices affect almost all economic sectors (Abdullah, Saiti \& Masih, 2016, 219). Gold is seen as the leading investment instrument and the leading commodity on the metal markets. In addition, gold is seen as a reliable port in order to avoid excessive risk on financial markets and an important risk management tool in hedging and portfolio diversification since it is less sensitive to the exchange rate fluctuations (Hussin, Muhammad, Razak, Tha \& Marwan, 2013, 162). In fact, gold is an entity possessing the desired properties of money. This is because, unlike many other commodities, gold is durable, easily distinguishable, storable, portable and divisible and easily standardized (Baur, 2013, 5).

Islamic banks have a share of approximately $73 \%$ in the global Islamic finance sector. However, the general trend in this field is shifting from banking to Islamic capital market instruments with higher growth rates.

Table 1 The types of commodities

\begin{tabular}{llllll}
\hline Energy Products & \multicolumn{1}{c}{$\begin{array}{c}\text { Precious } \\
\text { Metals }\end{array}$} & $\begin{array}{c}\text { Other Metals \& } \\
\text { Minerals }\end{array}$ & $\begin{array}{c}\text { Agricultural } \\
\text { Products }\end{array}$ & $\begin{array}{c}\text { Soft } \\
\text { Commodities / } \\
\text { Other Plants }\end{array}$ & $\begin{array}{c}\text { Animal } \\
\text { Products }\end{array}$ \\
\hline Brent oil & Gold & Aluminum & Wheat & Coffee & Livestock \\
Crude oil & Silver & Copper & Corn & Cocoa & Milk \\
Natural Gas & Platinum & Zinc & Cotton & Sugar & \\
Electric & Palladium & Lead & Potato & & \\
Kerosene & & Tin & Rice & & \\
Heating fuel & & & Orange juice & & \\
Carbon emissions & & & & & \\
\end{tabular}

Source: Koy, 2018, 23. 
The most common of these instruments are Islamic stock indices and Islamic investment funds (Buğan, 2016, 250). In short, Islamic stock indices (Buğan, 2016, 251), which can be defined as the indices of the enterprises that meet the determined Islamic criteria, or participation indices with the name used in our country are one of the most important instruments of Islamic capital markets (Hussin et al, 2013, 167). The less risky nature of Islamic stock markets and the extraordinary growth rate of these indices increase demand for these indices and are considered as one of the biggest innovations in the financial field (Raza, Ibrahimy \& Ali, 2015, 4).

In general, Islamic indices (participation indices) must be in line with the Islamic criteria, unlike conventional indices. These criteria consist of the two stages: as the main activity area criteria and the financial criteria. According to the main activity area criteria, firms' main activities to be included in the index should only be in the areas deemed appropriate by Islam. In order to be able to enter the index according to financial criteria, companies should provide certain financial ratios calculated as Total Interest Loans/Market Value, Interest Income Cash and Securities/Market Value and Income from the Activities Specified in the First Criterion/Total Value (www.katilimendeksi.org). However, these criteria for Islamic indices are not completely standard for each country or each index calculator. The mentioned criteria may differ in terms of the determined values for the activity and the financial ratios (Derigs \& Marzban, 2008, 289; Buğan, 2016, 252-255).

The analysis of the linkages between commodities and Islamic capital markets attracts financial actors' attention, especially as commodities are included in many investment portfolios together with a raw material and stock classes (Khan \& Masih, 2014, 4). According to the ICD - Thomson Reuters (2017) Interest-Free Finance Development Report, the total assets of the global interest-free finance system grew by almost $10 \%$ compared to the previous year, having reached $\$ 2.417$ billion by the end of 2017 . According to the estimates, the total Islamic finance assets are anticipated to reach $\$ 3.8$ trillion by 2022 . This corresponds to an average annual growth of approximately $10 \%$. The total value of the capital market products in Islamic financial assets was determined to be $\$ 509$ billion by the end of 2017, and is expected to exceed US \$1 trillion by 2022 . Demonstrating the interaction between such a fastgrowing sector and commodity markets will enable the provision of important information to both investors and portfolio managers.

The first aim of this study is to determine whether the investors who invest in Islamic stock indices in Turkey can invest in gold or Brent oil for the purpose of their portfolio diversification. The other aim of the study is to determine whether Islamic stock index returns can be predicted by using the commodity market data. Thus, whether the Islamic markets operating on the basis of asset-based financing are related to commodity markets will be revealed.

In this context, the hypotheses of the study will be as follows:

H1: An investor investing the Participation-30 Islamic Stock Index in Turkey can invest in gold and Brent oil for the purpose of his portfolio diversification.

H2: Gold and Brent oil price data can be used to predict the Participation-30 Islamic Stock Index in Turkey.

H3: There is a relationship between Islamic markets and the commodity markets operating in accordance with the principle of asset-based financing.

In order to attain the goals of the study, long-term cointegration and the causality relationship between the Participation-30, as one of the Islamic stock indices in Turkey, on the one hand, and commodity markets, on the other, are being tested. The papers on this subject matter have been written in Far-East Asian countries such as Malaysia, which has developed Islamic markets, and in Gulf countries. However, the Turkey's example has not previously been seen in any paper. This situation reveals the specificity of the study. In terms of the method, the fact that it is the first study to be examining the relationship between 
the participation indices and commodity markets by using the Fourier form tests that take into account many transient structural breaks with smooth transition reveals yet another unique aspect of the study.

The study consists of five chapters. Following the introduction part, a review of the literature is given in the second section. In the third chapter, the scope and methods of the study are explained. After the findings have been presented in the fourth section, the results and the suggestions are given in the final section.

\section{LITERATURE REVIEW}

The relationship between commodity markets and stock markets has never lost its importance and has been included in a wide research area. In the literature, the relationships between oil and conventional stock returns have been researched more heavily than commodity markets (Jones \& Kaul, 1996; Sadorsky, 1999; Basher \& Sadorsky, 2006; Büyükşahin, Haigh \& Robe, 2008; Narayan \& Sharma, 2011; Fahami, Haris $\&$ Mutalib, 2014). On the other hand, the relationships between the conventional stock market indices and the Islamic stock market indices have been studied in a significant number of studies in terms of portfolio diversification (Saiti, Bacha \& Masih, 2014; Nazlioglu, Hammoudeh \& Gupta, 2015; Bahloul, Mroua \& Naifar, 2017; Jebran, Chen \& Tauni, 2017). In this study, the relationships between commodity prices and Islamic indices are discussed. Previous studies of these relationships are presented in this part of the study.

The first studies to have been investigating the relationship between Islamic markets and commodity prices are those conducted by Hussin and his colleagues. M. Y. M. Hussin, F. Muhammad, K. Noordin, N. F. Marwan and A. A. Razak (2012a) focused on the impact of shocks in oil prices and macroeconomic variables on the Islamic stock market in Malaysia. In the study, the VAR model, the Johansen-Juselius Cointegration Test and the VECM Granger Causality Test were applied to the January 2007 - December 2011 period. According to the findings, cointegration between the Islamic stock prices, the oil price and the selected macroeconomic variables was established. According to the Granger causality, no relation was found between the Islamic stock prices and the crude oil price.

M. Y. M. Hussin, F. Muhammad, M. F. Abu and A. A. Razak (2012b) investigated the relationship between the Islamic stock markets, the oil price and the macroeconomic variables for Malaysia. The VAR model, the Johansen-Juselius Cointegration Test and the Granger Causality Test were used in the study. As a result of the paper, the Islamic stock prices were seen as being cointegrated together with the exchange rate and the oil price variables. Based on the cointegration analysis, the Islamic stock price was positively and significantly correlated with the oil price variable. According to the Granger Causality Test Analysis, the oil price variable was the Granger cause of the Islamic stock market return in Malaysia.

Hussin et al (2013) investigated the relationship between the FTSE Bursa Malaysia Emas Shariah Index and strategic commodities (crude oil and Kijang gold). The study covered the January 2007 December 2011 period, and included the VAR model, the Johansen-Juselius Cointegration Test and the Granger Causality Test. According to the findings, no cointegration relationship was found between the FTSE Bursa Malaysia Emas Shariah Index and strategic commodities. Moreover, a two-way causality relationship between this index and crude oil prices was established, whereas no causality among the Kijang gold prices was found.

A. Khan and M. Masih (2014) investigated the relationships between energy indices, precious metals, agricultural products, non-ferrous metals and soft products spot indices with the Dow Jones Islamic Index. In addition, the Dow Jones Spot Commodity Index was included as the total commodity price index. The MGARCH-DCC model was used in the study covering the period from January 3, 2001 to March 28, 2013. According to the findings of the study, the relations between the commodity and the Islamic stock markets were seen to have developed over time and to have been quite variable, especially since the 
2007-2008 global financial crisis. While an uncertain level of speculation was highlighted for the energy sector (oil), the safe haven role of the precious metal (gold) sector was proven.

The main purpose of the study conducted by S. H. M. Rithuan, A. M. Abdullah and A. M. M. Masih (2014) was the examination of the causal nexus between the crude oil price and the Islamic Stock Index in the Gulf Cooperation Council member countries (the UAE, S. Arabia, Qatar, Kuwait, Bahrain and Oman). The prices of the other commodities, such as corn and gold prices, were also included in the study as the control variables and the robustness tests. According to the results of the study, cointegration between the Islamic stock indices and commodities was identified by applying the Vector Error Correction Model (VECM), the Johansen Cointegration Test and the Wavelet (Wavelet) Approach. The Islamic stock indices and the crude oil prices in Saudi Arabia and Oman were found to lead to the other Islamic stock indices and commodities. According to the Discrete Wavelet Transform (MODWT) technique, the crude oil price leads to the other Islamic indices in the short run. According to the Continuous Wavelet Transform (CWT) technique, if the investor's investment period is less than 128 days, they will benefit from portfolio diversification.

T. Chebbi and A. Derbali (2015) investigated the links between Islamic capital markets (the QE Al Rayan Islamic Index) and strategic commodities (crude oil and natural gas). The GARCH-DCC method was used in the study and the results showed that the volatility in commodity returns was strongly related to the $\mathrm{QE}$ Al-Rayan Islamic Index, and this result affected the financialization of commodity markets.

While investigating the role of safe-haven assets in the fields of time and frequency, N. Raza, A. Ibrahimy and A. B. Ali (2015) compared gold and the Dow Jones Islamic World Emerging Market Index for two different crisis periods. Kao Panel Cointegration Tests, the Pooled Mean Group (PMG) Estimator, and the Wavelet Approach were applied in the study. According to the findings, the Islamic emerging markets and the BRICS stock markets were cointegrated and gold would be the portfolio diversifier of the Islamic stock markets.

The main purpose of the study conducted by A. M. Abdullah, B. Saiti and M. Masih (2016) was to investigate the dynamic causal relationship between commodity prices (crude oil, corn and gold) and the Islamic Stock Indices in Southeast Asian countries (Singapore, Philippines, Indonesia, Thailand and Malaysia). Gold and corn prices were included in the study as the control variables and the robustness tests. In the study, the Johansen Cointegration Test, the VECM-Granger Causality Test, the Wavelet Technique (MODWT and CWT), and the MGARCHDCC model were applied. According to the findings, the Islamic stock indices and the commodity prices in the Southeast Asian countries were moving together in the long run. The Malaysian Islamic stock market indices had the lowest volatility.

M. K. Nejad, F. Jahantigh and H. Rahbari (2016) investigated the relationship between the oil price risk and the Tehran stock return for the January 2003-October 2014 period. The Gregory-Hansen, Saikkonen-Lütkepohl and Johansen-Juselius Cointegration Tests were done and a long-term relationship between Tehran Stock Index and the oil price was found.

In their study, K. M. Kisswani and M. I. Elian (2017) used the non-linear ARDL (NARDL), the JohansenJuselius Cointegration Test, the Error Correction Model and the Granger Causality Tests to investigate the relationship between the Kuwait Stock Market (10 main sectors) and oil prices (West Texas and Brent). According to the study's findings, the oil prices and some Kuwaiti sectoral stock prices showed asymmetric long-term effects. In addition, while the empirical results for these sectors demonstrated a short-term asymmetric effect in the case of the WTI price measure, no evidence of an asymmetric effect was found, but there was a symmetric effect in the case of the price of Brent oil.

The studies mentioned are summarized in Table 2. 
Table 2 The literature review

\begin{tabular}{|c|c|c|c|c|c|c|}
\hline \multirow[b]{2}{*}{ Source } & \multirow{2}{*}{$\begin{array}{c}\text { Data } \\
\text { (Frequency) }\end{array}$} & \multicolumn{2}{|c|}{ Variables } & \multirow[b]{2}{*}{ Econometric Method } & \multicolumn{2}{|c|}{ Empirical findings } \\
\hline & & Stock exchange & Commodity & & Cointegration & Causality \\
\hline $\begin{array}{l}\text { Hussin et al, } \\
(2012 a)\end{array}$ & $\begin{array}{l}\text { January } 2007 \text { - } \\
\text { December } 2011 \\
\text { (Monthly) }\end{array}$ & $\begin{array}{l}\text { FTSE Bursa } \\
\text { Malaysia Emas } \\
\text { Shariah Index }\end{array}$ & Crude Oil & $\begin{array}{l}\text { Johansen-Juselius } \\
\text { cointegration test } \\
\text { VECM Granger causality } \\
\text { test }\end{array}$ & $=$ & No relationship \\
\hline $\begin{array}{l}\text { Hussin et al, } \\
(2012 b)\end{array}$ & $\begin{array}{l}\text { January } 2007 \text { - } \\
\text { December } 2011 \\
\text { (Monthly) }\end{array}$ & $\begin{array}{l}\text { FTSE Bursa } \\
\text { Malaysia Emas } \\
\text { Shariah Index }\end{array}$ & Crude Oil & $\begin{array}{l}\text { Johansen-Juselius } \\
\text { cointegration test } \\
\text { Granger causality test }\end{array}$ & $=$ & $\mathrm{EP} \rightarrow \mathrm{ISP}$ \\
\hline $\begin{array}{l}\text { Hussin et al, } \\
(2013)\end{array}$ & $\begin{array}{l}\text { January } 2007 \text { - } \\
\text { December } 2011 \\
\text { (Monthly) }\end{array}$ & $\begin{array}{l}\text { FTSE Bursa } \\
\text { Malaysia Emas } \\
\text { Shariah Index }\end{array}$ & $\begin{array}{l}\text { Crude Oil } \\
\text { Kijang Gold }\end{array}$ & $\begin{array}{l}\text { Johansen-Juselius } \\
\text { cointegration test } \\
\text { Granger causality test }\end{array}$ & $\neq$ & $\begin{array}{l}\mathrm{ISP} \leftrightarrow \mathrm{EP} \\
\text { (Petrol) }\end{array}$ \\
\hline $\begin{array}{l}\text { Khan and Masih } \\
\text { (2014) }\end{array}$ & $\begin{array}{l}03.01 .2001- \\
28.03 .2013 \\
\text { (Daily) }\end{array}$ & $\begin{array}{l}\text { DJ Islamic Price } \\
\text { Index }\end{array}$ & $\begin{array}{l}\text { DJ } \\
\text { Commodity } \\
\text { Indices }\end{array}$ & MGARCH-DCC & $\begin{array}{l}\text { This analysis } \\
\text { has not been } \\
\text { conducted. }\end{array}$ & $\begin{array}{l}\text { This analysis } \\
\text { has not been } \\
\text { conducted. }\end{array}$ \\
\hline $\begin{array}{l}\text { Rithuan, Abdullah } \\
\text { and Masih (2014) }\end{array}$ & $\begin{array}{l}\text { 01.01.2000- } \\
28.02 .2014 \\
\text { (Daily) }\end{array}$ & $\begin{array}{l}\text { Gulf Cooperation } \\
\text { Council Members } \\
\text { Islamic Markets }\end{array}$ & $\begin{array}{l}\text { Crude Oil } \\
\text { Gold } \\
\text { Corn }\end{array}$ & $\begin{array}{l}\text { Johansen cointegration } \\
\text { test, } \\
\text { Wavelet approaches } \\
\text { (MODWT and CWT) }\end{array}$ & $=$ & $\begin{array}{l}\text { ISP (S. Arabia and } \\
\text { Oman) and EP } \\
\text { (Petroleum) } \rightarrow \\
\text { Other ISP and EP }\end{array}$ \\
\hline $\begin{array}{l}\text { Chebbi and Derbali } \\
\text { (2015) }\end{array}$ & $\begin{array}{l}15.03 .2011 \\
-25.12 .2014 \\
\text { (Daily) }\end{array}$ & $\begin{array}{l}\text { Qe Al Rayan } \\
\text { Islamic Index }\end{array}$ & $\begin{array}{l}\text { Crude Oil } \\
\text { Natural Gas }\end{array}$ & GARCH-DCC & $\begin{array}{l}\text { This analysis } \\
\text { has not been } \\
\text { conducted. }\end{array}$ & $\begin{array}{l}\text { This analysis } \\
\text { has not been } \\
\text { conducted. }\end{array}$ \\
\hline $\begin{array}{l}\text { Raza, Ibrahimy and } \\
\text { Ali (2015) }\end{array}$ & $\begin{array}{l}01.01 .1996 \\
-31.12 .2014 \\
\text { (Daily) }\end{array}$ & $\begin{array}{l}\text { DJ Islamic World } \\
\text { Emerging Market } \\
\text { Index, BRICS } \\
\text { Commodity } \\
\text { Exchanges }\end{array}$ & Gold & $\begin{array}{l}\text { Kao Panel cointegration } \\
\text { tests } \\
\text { Wavelet approach }\end{array}$ & $=$ & $\begin{array}{l}\text { This analysis } \\
\text { has not been } \\
\text { conducted. }\end{array}$ \\
\hline $\begin{array}{l}\text { Abdullah, Saiti and } \\
\text { Masih } \\
(2016)\end{array}$ & $\begin{array}{l}\text { 01.06.2007- } \\
28.02 .2014 \\
\text { (Daily) }\end{array}$ & $\begin{array}{l}\text { Southeast Asian } \\
\text { Islamic Stock } \\
\text { Markets }\end{array}$ & $\begin{array}{l}\text { Crude Oil } \\
\text { Gold } \\
\text { Corn }\end{array}$ & $\begin{array}{l}\text { Johansen cointegration } \\
\text { test, Granger causality } \\
\text { test, Wavelet approaches } \\
\text { (MODWT and CWT), } \\
\text { MGARCH-DCC method }\end{array}$ & $=$ & $\begin{array}{l}\text { EP } \rightarrow \text { ISP } \\
\text { (Singapore, } \\
\text { Philippines and } \\
\text { Thailand) }\end{array}$ \\
\hline $\begin{array}{l}\text { Nejad, Jahantigh } \\
\text { and Rahbari (2016) }\end{array}$ & $\begin{array}{l}\text { January } \\
\text { 2003-October } \\
2014 \text { (Daily) }\end{array}$ & $\begin{array}{l}\text { Tehran Stock } \\
\text { Market }\end{array}$ & $\begin{array}{l}\text { OPEC Oil } \\
\text { Basket }\end{array}$ & $\begin{array}{l}\text { Cointegration tests (GH, } \\
\text { Saikkonen-Lütkepohl and } \\
\text { Johansen) }\end{array}$ & $=$ & $\begin{array}{l}\text { This analysis } \\
\text { has not been } \\
\text { conducted. }\end{array}$ \\
\hline $\begin{array}{l}\text { Kisswani and Elian } \\
\text { (2017) }\end{array}$ & $\begin{array}{l}\text { 03.01.2000- } \\
09.11 .2015 \\
\text { (Daily) }\end{array}$ & $\begin{array}{l}\text { Kuwait Stock } \\
\text { Exchange (10 Main } \\
\text { Sector) }\end{array}$ & Crude Oil & $\begin{array}{l}\text { N-ARDL } \\
\text { Granger causality tests }\end{array}$ & $=$ & $\begin{array}{l}\text { There are } \\
\text { different results } \\
\text { according to the } \\
\text { sector. }\end{array}$ \\
\hline
\end{tabular}

Note: ISP represents Islamic stock prices and EP represents commodity prices. In addition, " $\rightarrow$ " sign indicates one-way causality relationship, " $\leftrightarrow$ " sign indicates two-way causality relationship, "=" sign indicates cointegration relationship, and " $\neq$ "sign indicates that there is no cointegration.

Source: Authors 
According to the report presented in Table 2, the studies of commodity markets and Islamic markets or Islamic indices are quite limited. In addition, there is almost no study regarding this issue in Turkey. In this context, the fact that it is the first study to examine these relations in Turkish markets reveals the originality of the paper. Almost all of the studies have identified the cointegration relationship between commodity markets and Islamic markets or Islamic indices. The findings of causality were found to vary according to the country and the indices examined.

\section{ECONOMETRIC METHODOLOGY}

Structural changes are very important in a time series analysis. Structural improvements in time series can be caused for various reasons, such as economic crises, wars and political changes. The important issue at this point is that the structural changes cannot be determined by conventional econometric methods. For example, serious structural changes in time series are ignored when the ADF, the PP and the KPSS Unit Roots, the Johansen Cointegration, Granger and TodaYamamoto causality tests are applied. This situation may lead to false or inaccurate findings (Çil Yavuz, 2015, 308).

In this context, the literature shows us that both the unit root and the cointegration applications that take structural breaks into consideration are used. Thus, serious structural changes in data will not be overlooked. However, the disadvantage of these tests reflects in their not being capable of accounting for a large number of smooth-transition structural breaks. The authors identified shortcomings in the literature, and developed the Fourier unit root, cointegration and causality tests (Becker, Enders \& Lee, 2006; Enders and Jones, 2015; Tsong, Lee, Tsai \& Hu, 2015).

A Fourier series is an expansion of a periodic $y_{t}$ function in the form of an infinite sum of cosines and sinuses. The Fourier KPSS tests developed by $\mathrm{R}$. Becker et al (2006) use trigonometric functions to capture changes larger than the mean of the dependent variable. The advantage of this test is that it takes into account many smooth-transition structural breaks with smooth transition. The econometric model of this test, which is the Fourier extension of the KPSS (1992) Unit Root Test, can be explained in the following manner:

$$
y_{t}=\lambda_{0}+\lambda_{1} \sin \left(\frac{2 \pi k t}{T}\right)+\lambda_{2} \cos \left(\frac{2 \pi k t}{T}\right)+v_{t}
$$

where $T$ represents the sample size, $\lambda_{1}$ and $\lambda_{2}$ are the Fourier coefficients, $\pi$ is 3.11416, and $k$ is the frequency used to find the optimal value that makes the sum of the residual squares the smallest.

In order to carry out this test, it is first necessary that $k$, which is the total of the smallest residual squares, should be determined. After determining the appropriate frequency $(k)$, whether the F statistic obtained from this model is meaningful or not is decided by making comparisons with the critical values given by R. Becker et al (2006). In the final stage, the residual series of the selected model $\mathrm{k}$ is created and the traditional KPSS test is applied to the residual series of the series. In this way, the Fourier KPSS test is performed. According to this test, the null hypothesis indicates that the series is stationary and the alternative hypothesis indicates the existence of the unit root in the series (Beşel \& Uygun, 2017).

The second method used in the study is the Fourier Cointegration Test developed by C. C. Tsong et al (2015). This method uses the same mathematical structure as the FKPSS Unit Root Test. In this context, in the absence of the independent variable and the Fourier function, the results of the FKPSS Unit Root Test are obtained. In the absence of the Fourier function when there is an independent variable, the results of the $Y$. Shin (1994) Cointegration Test will appear. According to the test, the null hypothesis indicates the existence of cointegration and the alternative hypothesis shows that there is no cointegration (Y1lanc1, Aslan \& Özgür, 2017).

The last method used in the study was the Fourier Causality Test developed by W. Enders and P. Jones (2015). As the name implies, this test is the Fourier form of the traditional Granger Causality Test. While 
almost all of the causality tests in the literature fail to take into account structural breaks, this method takes such structural breaks into consideration in a smooth transition form. This test also operates in the same econometric logic as the Fourier Unit Root and the Fourier Cointegration Tests. The difference between the Fourier methods used in the study is in terms of the hypotheses. The null hypothesis indicates that there is no causality between the series, whereas the alternative hypothesis indicates the existence of such causality.

\section{DATA AND EMPIRICAL FINDINGS}

\section{Data}

The Participation-30 Index, which has the longest time interval amongst the Islamic indices in Turkey, was used in the study as a data set representing the Islamic indices, whereas the other variables were the Brent oil price expressed in dollars per barrel and the gold ounce as the basis of dollars. As can be seen in the literature in Table 2, oil and gold were generally used to represent the commodity variable. Therefore, the commodities mentioned in the literature were preferred in this study.

The data set ranges between $7^{\text {th }}$ Jan. 2011 and $4^{\text {th }}$ June 2018, on a daily basis. When the studies in the literature are examined, it is determined that the observation frequency is mostly used on a daily basis. The data for the Participation-30 Index were obtained from the Foreks website (www.foreks.com), the Brent oil data were available on the US Energy Information Management's website (www.eia.gov), whereas the gold ounce basis data were obtained from the World Gold Council's website (www.gold.org). In order to keep the data range broad, the other İstanbul Stock Market (Borsa Istanbul) Islamic Indices, the Participation-50 and the Participation Model Portfolio, whose historical data reach back in the year 2014, were not included in the study.

The logarithmic transformations of the series data were taken so as to prevent return volatility prior to performing the analysis. Moreover, during the Fourier Causality Tests, the findings were obtained by a 10,000 Monte Carlo Bootstrap Simulation.

The logarithmic time series graphs in the data ranges studied for the Participation-30, Brent Oil and Golden Ounce series are presented below (Figures 1, 2 and 3).

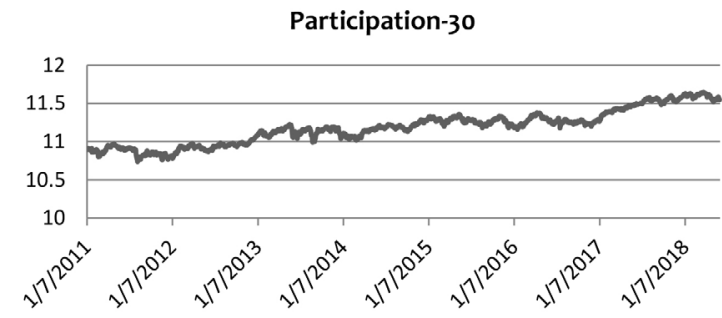

Figure 1 Participation-30 Index (Logarithmic)

Source: Authors

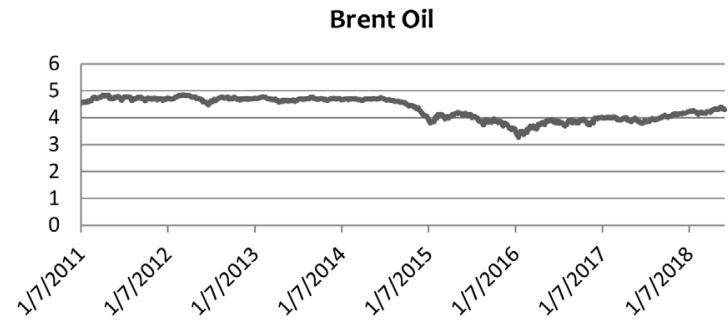

Figure 2 Brent Oil (Logarithmic)

Source: Authors

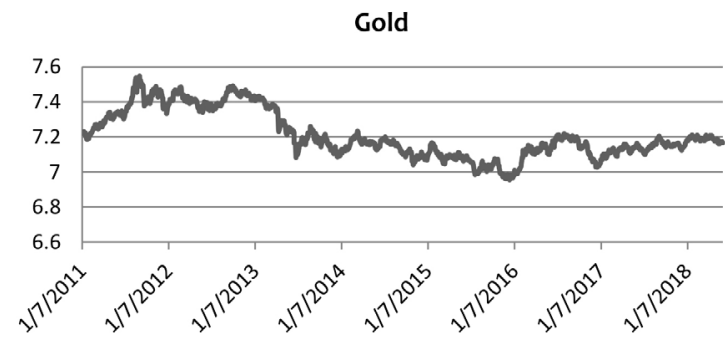

Figure 3 Gold Ounce (Logarithmic)

Source: Authors 


\section{Empirical Findings}

Following the disclosure of the data used, the first procedure is to determine the stationary order of the series. According to the results in Table 3, it is seen that all the three indices have the unit roots in the level forms and become stable as a result of the first difference-taking process. Because the level-value test statistics are higher than the critical values in R. Becker et al (2006), the test statistics obtained as a result of the first difference are lower than those critical ones.

Table 3 The Fourier KPSS Unit Root Test results

\begin{tabular}{l|ccc}
\hline Variables & $\mathrm{F}(\mathrm{k})$ & Level & $1^{\text {st }}$ Difference \\
\hline Participation-30 & 3 & 5.00 & $0.014^{* * *}$ \\
Brent Oil & 1 & 4.64 & $0.029^{* * *}$ \\
Gold Ounce & 1 & 3.49 & $0.014^{* * *}$ \\
\hline
\end{tabular}

Note: The critical values were obtained from R. Becker et

al (2006).

Source: Authors

It would be appropriate to investigate the cointegration relationship in such a case where the series are stationary in the first differences. The results of the Fourier SHIN Cointegration Test performed in this context are accounted for in Table 4. The H1 hypothesis, which indicates that there is no cointegration relationship for both matches, is accepted. In this context, an investor investing in the Participation-30 Index can invest in gold or Brent oil while diversifying its portfolio in order to reduce its risk.

Following the analysis of the unit root and the cointegration tests in the Fourier form, the causality test in the Fourier form is appropriate to use. According to the results of the Fourier Causality Test presented in Table 5 and developed by W. Enders and P. Jones (2015), no evidence of causality was found.
Table 4 The Fourier SHIN Cointegration Test results

\begin{tabular}{l|cccc}
\hline & MinSSR & $\mathrm{F}(\mathrm{k})$ & $\mathrm{Fm}(\mathrm{k})$ & $\mathrm{Tm}(\mathrm{k})$ \\
\hline $\begin{array}{l}\text { Cold Ounce and } \\
\text { Participation-30 }\end{array}$ & 19.98 & 2 & 14.80 & 0.67 \\
$\begin{array}{l}\text { Brent Oil and } \\
\text { Participation-30 }\end{array}$ & 38.91 & 3 & 3.55 & 2.39 \\
\hline
\end{tabular}

Note: The critical values for the Participation-30 and the gold ounce mapping were $0.078,0.099$ and 0.163 , at the level of significance of $\% 1,5$ and 10 , respectively. The critical values for the Participation-30 and the Brent oil mapping were $0.090,0.114$ and 0.170 at the level of significance $\% 1,5$ and 10 , respectively. These values were obtained from C. C. Tsong et al (2015).

Source: Authors

Table 5 The Fourier Granger Causality Test results

\begin{tabular}{|c|c|c|c|}
\hline The Direction of Causality & $\begin{array}{l}\text { Wald } \\
\text { Statistics }\end{array}$ & $\begin{array}{l}\text { Asymptotic } \\
\text { p-value }\end{array}$ & $\begin{array}{c}\text { Bootstrap } \\
\text { p-value }\end{array}$ \\
\hline Participation-30 $\rightarrow$ Brent Oil & 0.068 & 0.795 & 0.800 \\
\hline Brent Oil $\rightarrow$ Participation-30 & 1.239 & 0.266 & 0.263 \\
\hline $\begin{array}{c}\text { Participation-30 } \rightarrow \text { Gold } \\
\text { Ounce }\end{array}$ & 2.679 & 0.102 & 0.103 \\
\hline $\begin{array}{l}\text { Gold Ounce } \rightarrow \\
\text { Participation-30 }\end{array}$ & 1.340 & 0.246 & 0.236 \\
\hline
\end{tabular}

Source: Authors

\section{CONCLUSION}

The commodity market is the largest non-financial market in the world affecting a significant part of the world economy. The fact that the stock market performance can be affected by commodity markets makes the relationship between commodity markets and stock markets important. In addition to the other macroeconomic variables, commodity prices have 
been bearing special importance to the Islamic stock indices or the participation indices in our country in recent years because Islamic finance is a financial system based on the profit/loss sharing principle and is supportive of the activities carried out in the real sector in particular.

In this study, long-term cointegration and the causality relationships between the Islamic indices and the commodity markets in our country were investigated. Financial cointegration reveals the long-term relationships of the variables and provides investors with important pieces of information for their portfolio diversification. By means of the causality tests, the important other financial assets or market data forecasting clues are possible to obtain from a particular financial asset or market data. The daily data covering the period between $7^{\text {th }}$ Jan. 2011 and $4^{\text {th }}$ June 2018 were used in the study. In terms of the methodology, the relationship between the Participation-30 Index and commodity markets was examined by performing the Fourier form tests. In this context, the stability structures of the time series were examined through the Fourier KPSS Unit Root Test; the long-term relationships between the variables were investigated by applying the Fourier SHIN Cointegration Test, whereas the causality relations between the variables were examined by doing the Fourier Granger Causality Test.

According to the Fourier KPSS Unit Root Test used in the study, all of the three series (the Participation-30, Brent Oil and Ounce Gold) evidently have the unit roots in the level values and become stable as a result of the first difference-taking process. According to the Fourier SHIN Cointegration Test results, there is no long-term relationship between the Participation-30 Index and the ounce gold and Brent oil. In other words, an investor investing in the Participation-30 Index will be able to invest in gold or Brent oil while diversifying its portfolio in order to reduce its risk because an investor can diversify its portfolio by investing in the financial assets that do not act together in the long run. According to these results, the $\mathrm{H} 1$ hypothesis, assuming a portfolio diversification benefit amongst the variables, is accepted. The Fourier Granger Causality Test indicates no causality relationship to have been found between the Participation-30 Index and the ounce gold and Brent oil commodities. Thus, these variables will not be used together in making revenue estimates among financial assets. According to these results, the $\mathrm{H} 2$ and $\mathrm{H} 3$ hypotheses, assuming a relationship between the variables, are rejected. The results obtained by the Fourier SHIN Cointegration Test were compatible with Hussin et al (2013). On the other hand, the results obtained by the Fourier Granger Causality Test were in line with Hussin et al (2012a) and Hussin et al (2013) only for the gold ounce.

The study's most important result is that an investor investing in the Participation-30 Islamic Stock Indices in Turkey will be able to invest gold and Brent oil for his portfolio diversification. Another important result of the study is that, although the gold and the oil commodity markets are the world's largest nonfinancial markets, there is no causal relationship between the Islamic markets operating in the context of asset-based financing and the commodities mentioned. Thus, the gold and Brent oil price data cannot be used in the prediction of the Islamic Participation-30 Stock Index in Turkey.

There are several limitations of this study. First, as Islamic markets, especially so the Islamic Stock Indices, are relatively new in Turkey, the number of the observations that can be used in analysis is limited. On the other hand, the fact that the market is still very new also raises the question of the effectiveness of the market. For this reason, similar studies can be done again in subsequent periods, when these restrictions have been eliminated. Moreover, the relationship between the two other indices in our country (the Participation-50 and the Participation Model Portfolio) or the international Islamic indices and other commodities other than gold and Brent oil or international commodity indices can be investigated in future studies. In addition, the causality test performed in this study is related to causality in the mean. Future studies, however, may generate important pieces of information about the analysis of causality in variance or causality in frequency tests. 


\section{REFERENCES}

Abdullah, A. M., Saiti, B., \& Masih, M. (2016). The impact of crude oil price on islamic stock indices of South East Asian countries: Evidence from MGARCH-DCC and wavelet approaches. Borsa Istanbul Review, 16(4), 219-232. doi. org/10.1016/j.bir.2015.12.002

Bahloul, S., Mroua, M., \& Naifar, N. (2017). The impact of macroeconomic and conventional stock market variables on islamic index returns under regime switching. Borsa İstanbul Review, 17(1), 62-74. doi.org/10.1016/j.bir.2016.09.003

Basher, A. S., \& Sardorsky, P. (2006). Oil price risk and emerging stock markets. Global Finance Journal, 17(2), 224251. doi.org/10.1016/j.gfj.2006.04.001

Baur, D. (2013). Gold - Fundamental drivers and asset allocation. Retrieved May 20, 2018, from https://www.tdr.wiwi.uni-due. de/fileadmin/fileupload/VWL-WIPO/WiWi-Kolloquium/ Baur_Paper.pdf

Becker, R., Enders, W., \& Lee, J. (2006). A stationarity test in the presence of an unknown number of smooth breaks. Journal of Time Series Analysis, 27(3), 381-409. doi.org/10.1111/ j.1467-9892.2006.00478.x

Beşel, F., \& Uygun, U. (2017, October). The relationship between economic growth and tourism income: The case of Turkey. Paper presented na the 3rd SCF International Conference on Economic and Social Impacts of Globalization. Antalya, Turkey, 5-7.

Buğan, M. F. (2016). İslami hisse senedi endeksleri. In S. Erdoğan, A. Gedikli, \& D. Ç. Yıldırım (Eds.). İslam Ekonomisi ve Finansı (pp. 249-271). Kocaeli, Turkey: Umuttepe Yayınları.

Büyükşahin, B., Haigh, M. S., \& Robe, M. A. (2008). Commodities and equities: A "market of one". Retrieved May 30, 2018, from https://www.cftc.gov/sites/default/files/idc/groups/public/@ aboutcftc/documents/file/amarketofone_update0608.pdf.

Chebbi, T., \& Derbali, A. (2015). The dynamic correlation between energy commodities and Islamic stock market: Analysis and forecasting. International Journal of Trade and Global Markets, 8(2), 112-126. do1:10.1504/ijtgm.2015.069425

Çil Yavuz, N. (2015). Finansal Ekonometri. İstanbul, Turkey: Der Yayınları.
Derigs, U., \& Marzban, S. (2008). Review and analysis of current shariah-compliant equity screening practices. International Journal of Islamic and Middle Eastern Finance and Management, 1(4), 285-303. doi.org/10.1108/17538390810919600

Doyle, E., Hill, J., \& Jack, I. (2007). Growth in Commodity Investment: Risk and Challenges for Commodity Market Participants. London, UK: Financial Service Authority.

Enders, W., \& Jones, P. (2015). Grain prices, oil prices, and multiple smooth breaks in a VAR. Studies on Nonlinear Dynamics and Econometrics, 20(4), 399-419. doi.org/10.1515/ snde-2014- 0101.

Fahami, N. A., Haris, S., \& Mutalib, H. A. (2014). An econometric analysis between commodities and financial variables: The case of southeast Asia countries. International Journal of Business and Social Science, 5(7), 216-223.

Hussin, M. Y. M., Muhammad, F., Noordin, K., Marwan, N. F., \& Razak, A. A. (2012a). The impact of oil price shocks on Islamic financial market in Malaysia. Labuan e-Journal of Muamalat and Society, 6, 1-13.

Hussin, M. Y. M., Muhammad, F., Abu, M. F., \& Razak, A. A. (2012b). The relationship between oil price, exchange rate and Islamic stock market in Malaysia. Research Journal of Finance and Accounting, 3(5), 83-93.

Hussin, M. Y. M., Muhammad, F., Razak, A. A., Tha, G. P., \& Marwan, N. (2013). The link between gold price, oil price and Islamic stock market: Experience from Malaysia. Journal of Studies in Social Sciences, 4(2), 161-182.

ICD - Thomson Reuters. (2017). Islamic Finance Development Report 2017: Towards Sustainability. ICD-Thomson Reuters.

Jebran, K., Chen, S., \& Tauni, M. Z. (2017). Islamic and conventional equity index co-movement and volatility transmission: Evidence from Pakistan. Future Business Journal, 3(2), 98-106. doi.org/10.1016/j.fbj.2017.05.001

Jones, C. M., \& Kaul, G. (1996). Oil and the stock markets. The Journal of Finance, 51(2), 463-491. dor:10.2307/2329368

Junkus, J. C. (2010). Agricultural and metallurgical derivatives: Speculation and hedging. In R. W. Kolb, \& J. A. Overdahl (Eds.). Financial Derivatives: Pricing and Risk Management (pp. 77-87). New Jersey, USA: The Robert W. Kolb Series in Finance, JohnWiley \& Sons Inc. 89-101. 
Khan, A., \& Masih, M. (2014). Correlation between Islamic stock and commodity markets: An investigation into the impact of financial crisis and financialization of commodity markets. MPRA Paper No. 56979, Munich Personal RePEc Archive.

Kisswani, K. M., \& Elian, M. I. (2017). Exploring the nexus between oil prices and sectoral stock prices: Nonlinear evidence from Kuwait stock exchange. Cogent Economics \& Finance, 5(1), 1-17. doi.org/10.1080/23322039.2017.1286061

Koy, A. (2018). Türev Piyasalar: Emtia Türevleri, Opsiyonlar Vadeli İşlem Sözleşmeleri. Ankara, Turkey: Seçkin Yayıncılık.

Narayan, P. K., \& Sharma, S. S. (2011). New evidence on oil price and firm returns. Journal of Banking \& Finance, 35(12), 3253-3262. doi.org/10.1016/j.jbankfin.2011.05.010

Nazlioglu, S., Hammoudeh, S., \& Gupta, R. (2015). Volatility transmission between Islamic and conventional equity markets: Evidence from causality-in-variance test. Applied Economics, 47(46), 4996-5011. dor:10.1080/00036846.2015.1039 705

Nejad, M. K., Jahantigh, F., \& Rahbari, H. (2016). The long run relationship between oil price risk and Tehran stock exchange returns in presence of structural breaks. Procedia Economics and Finance, 36, 201-209. doi.org/10.1016/S22125671(16)30031-4

Raza, N., Ibrahimy, A., \& Ali, A. B. (2015). Gold and Islamic stocks a hedge and safe haven comparison in time and frequency domain for BRICS markets. Proceedings of the Asia Pacific Conference on Business and Social Sciences, Kuala Lumpur, Malaysia: MPRA Paper No. 69366.
Rithuan, S. H. M., Abdullah, A. M., \& Masih, A. M. M. (2014). The impact of crude oil price on Islamic stock indices of gulf cooperation council (GCC) countries: A comparative analysis. MPRA Paper No. 56989.

Sadorsky, P. (1999). Oil price shocks and stock market activity. Energy Economics, 21(5), 449-469. doi.org/10.1016/S01409883(99)00020-1

Saiti, B., Bacha, O. I., \& Masih, M. (2014). The diversification benefits from Islamic investment during the financial turmoil: The case for the US-based equity investors. Borsa İstanbul Review, 14(4), 196-211. doi.org/10.1016/j. bir.2014.08.002

Shin, Y. (1994). A residual-based test of the null of cointegration against the alternative of no cointegration. Econometric Theory, 10(1), 91-115. doi.org/10.1017/S0266466600008240

Tsong, C. C., Lee, C. F., Tsai, L. J., \& Hu, T. C. (2015). The Fourier approximation and testing for the null of cointegration. Empirical Economics, 51(3), 1085-1113. doi:10.1007/s00181-0151028-6

Yılancı, V., Aslan, M., \& Özgür, Ö. (2017). Testing the validity of PPP theory for African countries. Applied Economics Letters, 25(18), 1273-1277. doi.org/10.1080/13504851.2017.1418 066

FOREKS. https://www.foreks.com

KATILIM ENDEKSI. http://www.katilimendeksi.org

U.S. Energy Information Administration. https://www.eia.gov World Gold Council. https://www.gold.org

Received on $27^{\text {th }}$ October 2018, after revision, accepted for publication on $12^{\text {th }}$ December 2018 Published online on $28^{\text {th }}$ December 2018 
Şakir Sakarya is a professor at the Faculty of Economics and Administrative Sciences, Balıkesir University, Balıkesir, Republic of Turkey, as well as the Vice President of Balıkesir University. His main research areas include financial markets and institutions, investments and portfolio management, financial forecasting and modeling.

Feyyaz Zeren is an associate professor at the Faculty of Economics and Administrative Sciences, Yalova University, Yalova, Republic of Turkey. His main research areas include financial markets and institutions, investments and portfolio management, time series and panel data models in finance.

Hilmi Tunahan Akkuş is a lecturer at Savaştepe Vocational School, Balıkesir University, Balıkesir, Republic of Turkey, as well as an assistant director in Savaştepe Vocational School. His main research areas include Islamic finance, financial markets and institutions, investments and portfolio management, financial forecasting and modeling. 


\title{
RELACIJA ISLAMSKIH INDEKSA I ROBNIH TRŽIŠTA U TURSKOJ: PRISTUP ZASNOVAN NA FURIJEOVOM UČENJU
}

\author{
Şakir Sakarya', Feyyaz Zeren² i Hilmi Tunahan Akkuş ${ }^{1}$ \\ 'Department of Business Administration, Balıkesir University, Balıkesir, Turkey \\ 2Department of International Trade and Finance, Yalova University, Yalova, Turkey
}

Robno tržište, koje utiče na značajan segment svetske ekonomije, predstavlja najveće svetsko nefinansijsko tržište. Pored makroekonomskih varijabli, cene robe su posebno bitne za islamske berzanske indekse, koji su se poboljšali u poslednjih nekoliko godina, zato što islamske finansije predstavljaju finansijski sistem koji je zasnovan na načelu deljenja dobiti i gubitka i koji podržava aktivnosti koje se preduzimaju u realnom sektoru. U ovoj studiji je istraživana kointegracija i uzročno-posledična veza robnih tržišta (unce zlata i brent nafte) i Indeksa učešća-30 u Turskoj, koji je uspostavljen uzimanjem u obzir islamskih kriterijuma. Kao rezultat analize, nije dokazano postojanje kointegracije između Indeksa učešća-30 i robnih tržišta. Prema tim rezultatima, investitor koji ulaže u zlato ili naftu će, pored Indeksa učešća-30, diversifikovati svoj portfolio, sa ovom robnom investicijom, svodeći time rizik na najmanji mogući nivo. Činjenica da, prema rezultatima analize uzročno-posledične veze, ne postoji nikakav odnos između različitih varijabli, ukazuje na to da je struktura islamskih Indeksa učešća-30 nezavisna od robnih tržišta i konvencionalnih berzi.

Ključne reči: islamski Indeksi učešća-30, robna tržišta, pristupi koji se zasnivaju na Furijeovom učenju, diversifikacija portfolija

JEL Classification: G11, G15 